\title{
Gastric and jejunal histopathological changes in patients undergoing bariatric surgery
}

\author{
Rosemary Simões Nomelini RODRIGUES, Élia Cláudia de Souza ALMEIDA, \\ Júverson Alves TERRA JÚNIOR, Lucinda Calheiros GUIMARÃES, Ana Cristina da Rocha FUQUE and \\ Renata Margarida ETCHEBEHERE*
}

Received 6/9/2016

ABSTRACT - Background - Morbid obesity is a multifactorial disease that is increasingly treated by a arger, Objec... - To evaluate gastric histopathological changes in obese, and to compare with patients who underwent gastrojejunal bypass an we jejunal ncosa after the surgery. Methods - This is an observational study performed at a tertiary public hospital, evaluating endoscopic biopsies fron 36 preoperative patients and 35 postoperative. Results - In the preoperative group, $80.6 \%$ had chronic gastritis, which was active in $38.9^{\circ},(\mathrm{N}, 1 \%$ and $2.1 \%$, respectively, in the postoperative). The postoperative group had a significant reduction in Helicobacter pylori infection $(P=0.001)$. Inger length of the gastric stump and a time since surgery of more than two years were associated with Helicobacter pylori infection. The jeju 1 mucosa was normal in $91.4 \%$ and showed slight nonspecific chronic inflammation in $8.6 \%$. Conclusion - There was a reduction in the in tou of Holicobacter pylori infection in the postoperative group. A longer length of the gastric stump and longer time elapsed since surgery were asso iat a witn Helicobacter pylori infection. The jejunal mucosa was considered normal in an absolute majority of patients.

HEADINGS - Obesity. Bariatric surgery. Histology. Gastritis. Helicobacte pyw

\section{INTRODUCTION}

Obesity is a chronic disease characterized by cumulation of adipose tissue in the organism. Th dis increased in prevalence in recent decades, parti alarly in de loping countries, and the levels have nearly dou led between 1980 and $2014^{(5,9,25)}$. Obesity has a multifactorial etio 'ogy that depends on interactions among genetic, metabol social, woral, and cultural factors $^{(18)}$. Obesity requires a mult lever mroach for treatment, with dietary guidance, regular phys ? activity, and drugs being the main pillars of this tr atm $\mathrm{nt}$. $\mathrm{H}$ wever, conventional treatment for morbid obesity pro "re an atisfactory results, with around $95 \%$ of patients reg in to the initial weight within 2 years of treatment. According'y, bu riatric su.gery is increasingly being

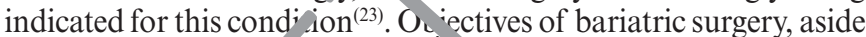
from weight loss, ar a reduction in the presence of comorbidities and an improvement ne patient's quality of life $\mathrm{e}^{(16)}$

Despite th $\mathrm{m}$ reas $\mathrm{d}$ iformance of bariatric surgery in recent years, ew st idies have investigated the histologic changes in the gastric mu osa or obese patients before surgery and in the mucosa of the Rou en-Y anastomosis after surgery. Therefore, the objectives of this study were to evaluate histopathologic changes to the gastric mucosa in obese patients who were about to undergo bariatric surgery, and to compare these changes to the gastric and jejunal changes found in patients who had undergone surgery at least 1 year earlier.

\section{METHODS}

This observational study was approved by the institution's ethics committee and performed at a tertiary public hospital from April 2014 to July 2015. Thirty-six patients were evaluated in the preoperative period before bariatric surgery (preoperative group) and 35 patients who had undergone surgery by the gastroduodenal bypass technique with Roux-en-Y reconstruction at least 1 year earlier (postoperative group). Patients who agreed to participate signed an informed consent form. Inclusion criteria were morbid obesity (BMI $>40 \mathrm{~kg} / \mathrm{m}^{2}$ ) and an indication for bariatric surgery or previous duodenal bypass with Roux-en-Y reconstruction performed at least 1 year earlier. Exclusion criteria were malformations or previous surgery in the upper gastrointestinal tract.

Clinical and demographic data were collected, such as gender, presence of comorbidities (e.g., diabetes mellitus, systemic hypertension, or depression), and BMI, during an interview before performing upper gastrointestinal endoscopy (UGIE). All patients underwent UGIE, which was performed using an Olympus videoendoscope device (GIF-Q150 ${ }^{\circledR}$ and GIF-2T160 ${ }^{\circledR}$ ) with an Exera-CLV-160 processor. During the exam, biopsies of the gastric body were collected from preoperative patients and biopsies of the gastric stump and jejunal mucosa from postoperative patients. The gastric body (oxyntic mucosa) was chosen in the preoperative group to enable comparisons with the gastric stump, which is usually of this type ${ }^{(22)}$.

Declared conflict of interest of all authors: none

Disclosure of funding: no funding received

* Universidade Federal do Triângulo Mineiro (UFTM), Uberaba, MG, Brasil.

Correspondence: Renata Margarida Etchebehere. Hospital de Clínicas, Serviço de Patologia Cirúrgica, UFTM. Rua Getúlio Guaritá, 130, Bairro Abadia - CEP: 38025-440 - Uberaba, MG,

Brasil. E-mail: renataetch@hotmail.com 
Biopsies were fixed in 4\% buffered formalin, processed, and encased in paraffin. They were stained with hematoxylin and eosin for general evaluation and with the Warthin-Starry stain for Helicobacter pylori (HP) research. Biopsies were evaluated for the presence or absence of the following criteria: erosion/ulceration, scarring, lymphatic follicles, mononuclear and polymorphonuclear inflammatory infiltrates (inflammatory activity), glandular body hypotrophy, intestinal metaplasia, reactive gastropathy, and bacteria that are morphologically compatible with HP. When applicable, the intensity of the features was quantified as absent, slight, moderate, or intense, as proposed by the 1996 Sidney Consensus ${ }^{(11,12)}$. A single medical pathologist analyzed all biopsies.

There was no statistical calculation to define the sample size, which was defined by accessibility because of the difficulties in making up the postoperative group. Results were entered into a database by using Microsoft Access $2000^{\circledR}$ and statistically analyzed by using the Biostat ${ }^{\circledR}$ program (version 5.0). Fisher exact and Mann-Whitney tests were applied, which were considered significant when the probability of rejecting the hypothesis was lower than $5 \%(P<0.05)$.

\section{RESULTS}

Table 1 summarizes the demographic characteristics of patients in the two groups. In the preoperative group, only $40 \%$ of patients had normal findings on UGIE. The remaining $60 \%$ had erosive or non-erosive gastritis $(54.3 \%)$, esophagitis $(14.3 \%)$, duodenitis $(11.4 \%)$, or polyp $(8.6 \%)$.

TABLE 1. Demographic and clinical information of patients in the and postoperative groups for bariatric surgery

\begin{tabular}{|c|c|c|}
\hline \multirow[b]{2}{*}{ Characteristics } & \multicolumn{2}{|c|}{ Group } \\
\hline & $\begin{array}{l}\text { Preoperative } \\
\qquad(\mathrm{n}=36)\end{array}$ & $\begin{array}{l}\text { Postope } \\
(n=35)\end{array}$ \\
\hline Age & $\begin{array}{c}40 \text { years old } \\
(\mathrm{md}=23-58)\end{array}$ & $\begin{array}{l}y, \text { rs old } \\
d=2, \quad 64\end{array}$ \\
\hline $\begin{array}{l}\text { Sex } \\
\text { Women } \\
\text { Men }\end{array}$ & $\begin{array}{c}30(83.3 \%) \\
6(16.7 \%\end{array}$ & $\begin{array}{r}31(38.6 \%) \\
(11.4 \%)\end{array}$ \\
\hline BMI $\left(\mathrm{kg} / \mathrm{m}^{2}\right)$ & & $\begin{array}{c}29.9 \pm 5.4 \\
(24.9-46.0) *\end{array}$ \\
\hline $\mathrm{SH}$ & & $17.1 \% * *$ \\
\hline DM & & $11.4 \% * * *$ \\
\hline Osteoarticular dis & & $2.9 \%$ \\
\hline Depression & $25.0 \%$ & $20.0 \%$ \\
\hline
\end{tabular}

BMI: body mass index; Sh systemic hypertension; DM: diabetes mellitus. $* P<0.0001$ $* * P=0.0000$

The time $\mathrm{s}$ nce surgery in the postoperative group ranged from 1 to 15 years (m) dian: 7 years), with $17.1 \%$ of patients having a time since surgery between 1 and 2 years, $14.3 \%$ between 2 and 5 years, and $60 \%$ of 5 or more years. The length of the remaining gastric stump ranged from 3 to $10 \mathrm{~cm}$. The length was shorter than $4 \mathrm{~cm}$ in $2.9 \%$ of patients; between 4 and $6 \mathrm{~cm}$ in $65.7 \%$ of patients; and longer than $6 \mathrm{~cm}$ in $31.4 \%$ of patients. On UGIE, $91.4 \%$ of postoperative patients had description of normal gastric stump and jejunum mucosa.
Table 2 shows the histopathological findings in the oxyntic gastric mucosa for the preoperative and postoperative groups. In the preoperative group, $80.6 \%$ of patients had chronic inflammation of the oxyntic gastric mucosa, which was classified as slight $(44.4 \%)$, moderate $(30.6 \%)$, or intense $(5.6 \%)$. Inflammatory activity was present in $38.9 \%$ of preoperative patients, classified as slight in $25 \%$, moderate in $5.6 \%$, and intense in $8.3 \%$ of patients. HP infection was present in $63.9 \%$. In the postoperative group, $77.1 \%$ of patients had chronic gastritis, which was classified as slight $(57.1 \%)$, moderate $(17.1 \%)$, or intense $(2.9 \%)$. Inflammatory activity was present in $20.1 \%$ of postoperative patients, and was classified as slight in $8.6 \%$, moderate in $8.6 \%$, an ${ }^{\prime}$ intense in $2.9 \%$ of patients. HP infection was present in $28.6 \%$.

TABLE 2. Histopathological fin 'ings in the $x$ itic gastric mucosa for patients in the pre- and postoperati groups

\begin{tabular}{|c|c|c|}
\hline & $\begin{array}{c}\text { Preop ative } \\
\quad(1=36)\end{array}$ & $\begin{array}{l}\text { Postoperative } \\
\quad(\mathrm{n}=35)\end{array}$ \\
\hline Erosion / & 0 & 0 \\
\hline Scarring & 0 & 0 \\
\hline Lymp & $8.3 \%$ & $22.9 \%$ \\
\hline Chronic in nmatron & $80.6 \%$ & $77.1 \%$ \\
\hline ory au ivity & $38.9 \%$ & $20.0 \%$ \\
\hline Hyp sphy & 0 & $5.7 \%$ \\
\hline Intestinal metaplasia & 0 & $5.7 \%$ \\
\hline eactive gastropathy & 0 & 0 \\
\hline Helicobacter pylori & $63.9 \%$ & $28.6 \% *$ \\
\hline
\end{tabular}

Representative histologic sections for the two groups are provided in Figure 1.

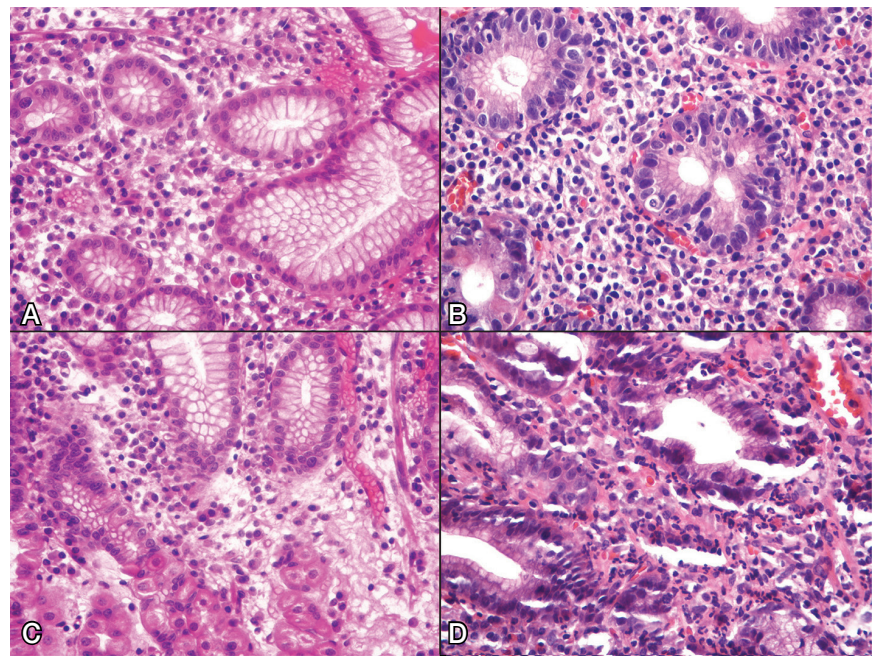

FIGURE 1. Histological slices of oxyntic mucosa in the pre- (A) and postoperative groups (B), with chronic gastritis characterized by a large quantity of plasma cells on the corion; C and D show the inflammatory activity, characterized by the permeation of the epithelium by neutrophils (hematoxylin and eosin, $400 \times$ ). 
One HP-positive case had a residual stump length smaller than $4 \mathrm{~cm}(10 \%)$, four cases had a stump length between 4 and $6 \mathrm{~cm}$ $(40 \%)$, and five cases had a stump length exceeding $6 \mathrm{~cm}(50 \%)$. Statistical analysis showed a significant relationship $(P=0.0001)$, suggesting that stumps with a length greater than $6 \mathrm{~cm}$ were more often associated with HP infection (Figure 2).

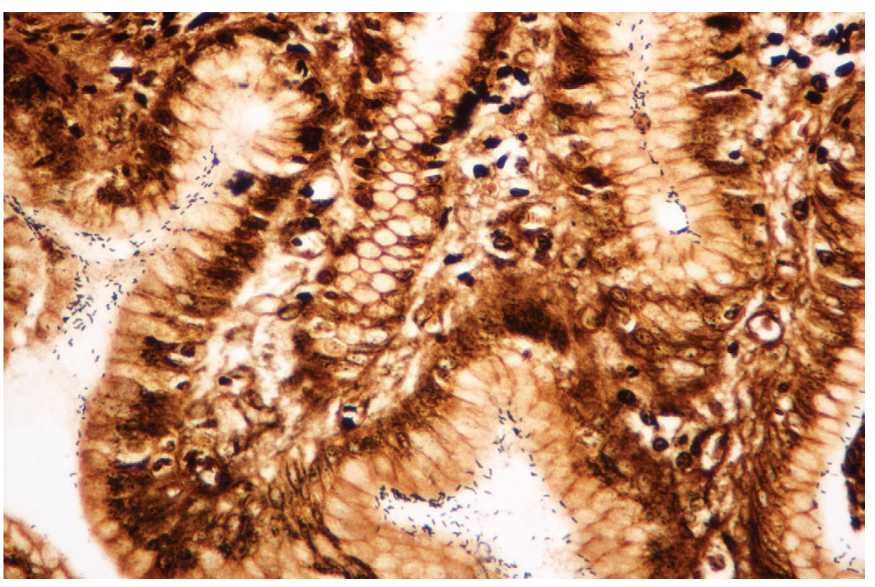

FIGURE 2. Histological slices of oxyntic gastric mucosa in the postoperative group, showing numerous spiraled bacteria (in black) on the surface of the epithelium and in the interior of the crypt compatible with HP infection (Wartin-Starry, 400×).

The time since surgery was compared with the presence of HP infection. None of the patients who had undergone surgery in the previous 2 years were infected with HP. In contrast, HP infections were found in five patients who underwent surgery between 2 and 5 years earlier, and in five patients who underwent surgery more than 5 years earlier. Statistical analysis showed a significant relationship ( $P=0.0014)$, suggesting that a time since surgery of 2 or more yea $s$ was more often associated with HP infection.

When comparing the BMI $\leq 30 \mathrm{~kg} / \mathrm{m}^{2}$ and $\geq 35 \mathrm{~kg} / \mathrm{m}^{2}$ in the postoperative group with HP infection, statistically significant ilference was not found ( $P=0.5835$ and 0.6879 , respectively).

Finally, when the jejunal Roux-en-Y mucosa was nalyzed $91.4 \%$ of postoperative patients had mucosa th could sidered histologically normal. The remaining $8.6 \%$ of pa iants had slight, nonspecific chronic inflammation.

\section{DISCUSSION}

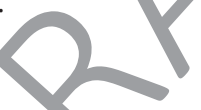

Obesity is a multifactorial chr nu disease that is increasingly being treated with surgery ${ }^{(5,9,18,25)}$. Cons, tent with the literature we found elevated levels of $c$ morbidities $1 \mathrm{~h}$ obese patients in the preoperative period ${ }^{(9,16,21)}$. Afu ${ }^{\prime}$ argery, as expected, there was a significant reduction in P.' and the ncidence of comorbidities, such as diabetes mellit s and svstemı hypertension. We frequently observed chronic gastn 5 in boin groups. Infection with HP, the main cause of gastritis " was significantly more common in preoperative than in postoperative patients. This bacteria is very prevalent worldwide. In a study performed in Brazil, Ddine et al. ${ }^{(10)}$ observed HP infection in around $18.5 \%$ of obese patients, a lower frequency than was observed in this study. Yang et al. ${ }^{(26)}$ analyzed patients who had undergone vertical gastroplasty or Roux-en-Y gastric bypass and observed HP infection in both symptomatic $(39 \%)$ and asymptomatic (39.7\%) patients after surgery.
Obesity, gastritis, and HP infection are not necessarily associated, although studies suggest that HP infection can affect food consumption through ghrelin, a peptide secreted in the stomach. There is a physiological rise in ghrelin levels during fasting, which increases appetite. Eating causes a reduction in ghrelin secretion and, consequently, of appetite. HP-induced gastritis can lead to reductions in ghrelin levels and body mass. Therefore, eradication of the bacteria normalizes ghrelin levels, increasing bodyweight. However, this idea remains controversial. Some studies have indicated a weight gain with infection, while others have not observed a change in ghrelin levels with HP infection ${ }^{(4,13)}$. Wang et al. ${ }^{(24)}$ observed that patients infected with HP and who hav gastritis exhibit significantly less weight loss when followed for 24 tr $>48$ months after surgery. Our findings indicated no associatio betwen HP infection and higher BMI in postoperative oroup.

A reduction in the occurrence of $\mathrm{H}^{\mathrm{D}}$ infe ion in patients who undergo an operation might be explai ed by the th $a^{+}$nent protocol, which seeks to eradicate the bacteria $b$ fore surg ry and, thus, avoid surgical complications $^{(2,17)}$. In gas "ojeju al by ass, the Roux-en-Y is made into a pouch (gastri stum $_{\mathbf{N}}$ ), dommated by the greater curvature and, sometimes in ted to the cardia, which reduces the population of parietal cells. Hover, Siilin et al. ${ }^{(22)}$ considered it to be practically impo sib. to mako a pouch that does not contain parietal cells. These chni or aspects lead to a reduction in the occurrence of marginal ulc rand HP infection. Csendes et al. ${ }^{(6)}$ found that HP infectio presen in $46.8 \%$ of patients before gastroplasty compared to 31 aft 1 rgery. Of the patients with HP infection after surgery, $50 \%$ re already carriers of the bacteria before surgery. The authors sugges, that despite there being few parietal cells in the gast ic pouc. HP was able to colonize it anew. An interesting finding of a present tudy is that patients who had undergone surgery more than 2 , rears reviously had a significant increase in HP infection. Th resur ouggests that the passage of time increases the chances tat HP will recolonize the mucosa.

$\mathrm{St}$ dies after partial gastrectomy and Roux-en-Y anastomosis for benign disease demonstrated there are a total of $41 \%$ of patients presented HP reinfection at the gastric stump, which increased parallel to the length of follow-up ${ }^{(7)}$. We observe much lower percentage in our study. A possible explanation for this difference is small gastric stump after gastric bypass left in bariatric surgery, as compared to surgery performed for benign disease (gastric pouch with the remaining eight to ten times greater) ${ }^{(7)}$. Agreeing with this impression, we found significant difference in the length of residual gastric stump with HP infection, suggesting that stumps larger than $6 \mathrm{~cm}$ would be more associated with this infection. However, further studies are needed. On the other hand, it is not fully established if the colonization of the gastric stump by HP after bypass is associated with complications ${ }^{(7,17)}$. Evaluation of the stump size by UGIE is a subjective evaluation that is influenced by the surgical technique. Previous authors have suggested ideal stump sizes ranging from 1.8 to $8.0 \mathrm{~cm}^{(1,15)}$. Moreover, our study included very few patients with a gastric stump smaller than $3 \mathrm{~cm}$. Other authors, analyzing the gastric pouch and the presence of HP, have found no association between the presence of HP and the gastric pouch or gastrojejunal anastomosis size. These authors concluded that the behavior of HP is inconsistent and difficult to interpret ${ }^{(8)}$.

Levels of gastritis in the gastric stump vary in the literature. We observed chronic gastritis, usually slight, in the majority of cases. Marano ${ }^{(19)}$ found normal endoscopic results in $30 \%$ of postoperative patients, although all patients who underwent UGIE 
were symptomatic. On the other hand, Marcuard et al. ${ }^{(20)}$ reported acute or chronic gastritis in all patients. Flickinger et al. ${ }^{(14)}$ performed UGIE on patients 13 to 20 months after surgery, and the pouch was described as endoscopically normal in $85 \%$ of patients. However, histology showed normality in only $45 \%$, acute gastritis in $23 \%$, chronic gastritis in $30 \%$, and intestinal metaplasia in $13 \%$ of patients. Our percentage of patients with chronic gastritis was higher and that of intestinal metaplasia lower than those reported in this previous study. In addition, we did not find any cases of acute gastritis. When analyzing the gastric pouch 2 years after surgery, other authors showed endoscopic normality in $99 \%$ of patients. Histology was normal in $56 \%$, gastritis was present in $28.1 \%$, and intestinal metaplasia was present in $4.0 \%$ of patients. Csendes et al. ${ }^{(6)}$ also studied the mucosa of the intestinal loop, which was normal in all patients, both macroscopically and histologically. Our findings were similar to those described by these authors.

\section{CONCLUSION}

A significant reduction in the percentage of patients with HP infection after bariatric surgery was observed. A residual gastric stump length exceeding $6 \mathrm{~cm}$ and a time since surgery exceeding 2 years were associated with a higher rate of HP infection. Our findings indicated no association between HP infection and higher BMI in postoperative group. The jejunal mucosa was considered normal in an absolute majority of patients.

\section{Authors' contributions}

Rodrigues RSN, Almeida ECS a a Etchebehere RM: project design, study development, data an lysis and interpretation and preparation of the article; Terra Júnl JÁ, Cuimarães LC and Duque ACR: preparation of the scientific acle and review.

Rodrigues RSN, Almeida ECS, Terra Júnior JA, Guimarães LC, Duque ACR, Etchebehere RM. Altera ões histopatológicas gástricas e jejunais em pacientes submetidos à cirurgia bariátrica. Arq Gastroenterol. 2017,54(1):75-8.

RESUMO - Contexto - A obesidade mórbida é doença multifatorial cujo tratamento cirúrgico é cada vu mals mndicado. Objetivo - Avaliar alterações histopatológicas gástricas em obesos e comparar com os submetidos à bypass gastrojejun a mucosa junal após a operação. Métodos - Estudo observacional realizado em hospital público terciário avaliando biópsias endoscópicas de 36 pa ientes no pré-operatório e 35 no pós-operatório. Resultados - No pré-operatório 80,6\% apresentaram gastrite crônica, 38,9\% em ativ ada (77,1\% e $20,1 \%$, respectivamente, no pós-operatório). O grupo pós-operatório apresentou diminuição significativa na infecção por Helicoba ter $p$ Lne $(P=0,0001)$. Maior comprimento do coto gástrico e tempo de operação superior a dois anos associaram-se a infecção por Helicobacter pylo A mucosa jejunal foi normal em 91,4\% e apresentava leve inflamação crônica inespecífica em 8,6\%. Conclusão - Houve diminuição da î nucão por ^ elicobacter pylori após a operação. Maior comprimento do coto gástrico e do tempo de operação associaram-se à infecção por Helico acte prori. A mucosa jejunal foi considerada normal na maioria absoluta dos pacientes do grupo pós-operatório.

DESCRITORES - Obesidade. Cirurgia bariátrica. Histologia. Gastrite. Helicobacter $p$. Jor

\section{REFERENCES}

1. Buchwald H, Williams SE. Bariatric surgery worldwide 2003. Obes ourg 2004;14:1157-64.

2. Cerqueira RM, Correia MR, Vilar H, Manso MC. How effe ve is the qua rur concomitant Helicobacter pylori eradication therapy for ob se pat nts undergoing gastric bypass surgery? Obes Surg. 2016;26:1163-6.

3. Cheater L, Rodrigues Jr L, Faria CM, Pricoli TI. rastrites. In: Mis suten SJ. Guia de Gastroenterologia. 2 ed. Barueri: Manole, 2007. p. 31-38

4. Choi YJ, Kim N, Yoon H, Shin CM, Park YS, Park. 'H, et al. Ino ease in plasma acyl ghrelin levels is associated with abatement of dyspe $\mathrm{C}_{\mathrm{N}}$, foll , ving Helicobater pylori eradication. J Gastroenterol. 2016;5

5. Coutinho WF. Consenso Latino Americano ( Obe an Arq Bras Endocrinol Metab. 1999;43:21-67.

6. Csendes A, Smok G, Burgos A . En oscopic and histologic findings in the gastric pouch and the Roux limb. Cer g? t.mic bypa s. Obes Surg. 2006;16:279-83.

7. Csendes A, Burgos AM. Be avior o ne infectron by Helicobacter pylori of the gastric remmant after su' toal gastr tomy and Roux-en-Y anastomosis for benign diseases. J Gast oent urg. 2008;1 1 .1508-11.

8. Csends A, Smok G, Purgos AM, anobra M. Prospective sequential endoscopic and histologic str 1 es of the gastr pouch in 130 morbdily obese patients to Roux-in Y gastri bypa . Arq Bras Cir Dig. 2012;25:245-49.

9. Deitel M. Overview the operations for morbid obesity. In: Deitel M, Cowan Jr. GSM, allo Surge fo the morbidly obese patient. Toronto: FD Comunnication 2000, 0.81-90.

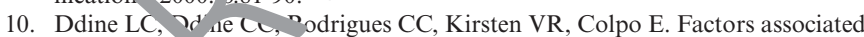
with chronic $g_{2}$ tritis in patients with presence and absence od Helicobacter pylori. Arq Bras Cir Dis 2012;25:96-100.

11. Dixon MF, Genta RM, Yardley JH, Correa P. Classification and grading of gastritis: The updated Sydney System. International workshop on the histopathology of gastritis, Houston 1994. Am J Surg Pathol. 1996;20:1161-81.

12. Eisig JN, Ferreira RPB. Doenças do estômago e duodeno. In: Martins MA Carrilho FJ, Alves VAF, Carrilho EA, Cerri GG, Wen CL, editors. Clínica médica: doenças do aparelho digestivo, nutrição e doenças nutricionais. Barueri: Manole; 2009. p.96-119.

13. Eren M, Colak Ö, Isiksoy S. Yavuz A. Effect of $H$. pylori infection on gastrin, ghrelin, motilin, and gastroesophageal reflux. Turk Gastroenterol. 2015;26:367-72.
4. Flickinger EG, Sinar DR, Pories WJ, Sloss RR, Park HK, Gibson JH. The bypassed stomach. Am J Surg. 1985;149:151-6.

15. Fobi MA, Lee H, Holness R., Cabinda D. Gastric bypass operation for obesity World J. Surg. 1998;22:925-35.

16. Karisson J, Sjöström L, Sullivan M. Swedish obese subjects (SOS): an intervention study of obesity. Two-year follow up of health-related quality of life (HRQL) and eating behavior after gastric surgery for severe obesity. Int J Obes Relat Metab Disord. 1998;22:113-26.

17. Kelly JJ, Perugini RA, Wang QL, Czerniach DR, Flahive J, Cohen PA. The presence of Helicobacter pylori is not associated with long-term anastomotic complications in gastric bypass patients. Surg Endosc. 2015;29:2885-90.

18. Kolotkin RL, Crosby RD, Kosloski KD, Williams GR. Development of a brief measure to assess quality of life in obesity. Obes Res. 2001;9:102-11.

19. Marano BJ Jr. Endoscopy after Roux-en-Y gastric bypass: a community hospital experience. Obes Surg. 2005; 15:342-5

20. Marcuard SP, Sinar DR, Swanson MS, Silverman JF, Levine JS. Absence of luminal intrinsic factor after gastric bypass surgery for morbid obesity. Dig Dis Sci. 1989;34:1238-42.

21. Prevedello, CF, Colpo E, Mayer ET, Copetti H. Análise do impacto da cirurgia bariátrica em uma população do centro do estado do Rio Grande do Sul utilizando o método Baros. Arq Gastroenterol. 2009; 46:199-203.

22. Siilin H, Wanders A, Gustavsson S, Sundbom M. The proximal gastric pouch invariably contains acid-producing parietal cells in Roux-en-Y gastric bypass. Obes Surg. 2005; 15:771-7.

23. Vasconcelos PO, Costa Neto SB. Qualidade de vida de pacientes obesos em preparo para cirurgia bariátrica. Psico. 2008;39:58-65.

24. Wang HH, Lee WJ, Liew PL, Yang CS, Liang RJ, Wang W, Lin JT, Wu MS. The influence of Helicobacter pylori infection and corpus gastritis on the postoperative outcomes of laparoscopic vertical banded gastropasty. Obes Surg. 2006;16:297-307.

25. World Health Organization. Obesity: preventing and managing the global epidemic - report of a WHO consultation on obesity. 2015. [Internet]. [Access 2015 October 28]. Available from: http://www.who.int/mediacentre/factsheets/fs311/es/.

26. Yang CS, Lee WJ, Wang HH, Huang SP, Lin JT, Wu MS. The influence of Helicobacter pylori infection on the development of gastric ulcer in symptomatic patients after bariatric surgery. Obes Surg. 2006;16:735-9. 


\title{
[Retracted article] Gastric and jejunal histopathological changes in patients undergoing bariatric surgery
}

\author{
Rosemary Simões Nomelini RODRIGUES, Élia Cláudia de Souza ALMEIDA, \\ Júverson Alves TERRA JÚNIOR, Lucinda Calheiros GUIMARÃES, \\ Ana Cristina da Rocha DUQUE and Renata Margarida ETCHEBEHERE
}

The Editorial Board of Archives of Gastroenterology, ISSN 1678-4219 online, decided, after analysis, to retract the article following:

Rodrigues RSN, Almeida ECS, Terra Júnior JA, Guimarães LC, Duque ACR, Etchebehere RM. Gastric and jejunal histopathological changes in patients undergoing bariatric surgery. Arq Gastroenterol. 2017,54(1):75-8. doi: 10.1590/S0004-2803.2017v54n1-15.

The submission process is based on the authors' ethics in ensuring exclusivity to a single journal. There are no means of submission and publication duplicity control in two jornals in near dates. 